Aksiologiya: Jurnal Pengabdian Kepada Masyarakat

Vol.4, No.2, Agustus 2020 Hal 248 - 252

ISSN 2528-4967 (print) dan ISSN 2548-219X (online)

\title{
Pelatihan Penulisan Karya Tulis IImiah Untuk Mendorong Peningkatan Kualitas Siswa Tingkat SMA
}

\author{
Ika Purnamasari ${ }^{1}$, Memi Nor Hayati ${ }^{2}$, Desi Yuniarti ${ }^{3}$ \\ ${ }^{1,3}$ Laboratorium Statistika Ekonomi dan Bisnis, Fmipa Universitas Mulawarman \\ ${ }^{2}$ Laboratorium Statistika Terapan, Fmipa Universitas Mulawarman \\ Email : ika.purnamasari@ymail.com,meminorhayati@yahoo.com,desiyuniarti@ \\ gmail.com
}

\begin{abstract}
ABSTRAK
Karya tulis ilmiah (KTI) merupakan karya ilmiah yang ditulis dengan mengikuti kaidah ilmiah. Kaidah ilmiah sebagai syarat utama dalam penulisan sebuah karya dimaksudkan agar karya yang dihasilkan dapat dipertanggung jawabkan secara ilmiah. Tujuan kegiatan pelatihan penulisan karya tulis ilmiah yaitu menumbuhkan minat, semangat, serta ide kreatif dan inovatif dari siswasiswi kelas X dan XI SMAN 5 Samarinda untuk menghasilkan sebuah karya ilmiah yang sesuai dengan kaidah penulisan. Berdasarkan hasil pelaksanaan kegiatan pelatihan dapat disimpulkan bahwa kegiatan berjalan dengan baik dan mendapat dukungan penuh dari pihak sekolah. Seluruh peserta pelatihan mengikuti kegiatan hingga akhir dengan tingkat kehadiran sebesar $100 \%$. Peserta kegiatan antusias untuk bertanya, mengeksplorasi ide, serta mengemukakan pendapat. Dengan demikian, kedepannya diharapkan adanya kegiatan lanjutan dengan melibatkan guru pendamping untuk mengoptimalkan perannya dalam penyusunan karya tulis ilmiah bagi peserta didik.
\end{abstract}

Kata Kunci: kaidah ilmiah, KTI, peserta didik.

\section{Training on Writing Scientific Papers to Encourage Quality Improvement of High School Level Students}

\begin{abstract}
The scientific paper is an essay written by following scientific rules that are the main requirement so that the resulting essay can be justified scientifically. The purpose of the training is to increase the interest, enthusiasm, creative, and innovative ideas from students of class $X$ and $X I$ of SMAN 5 Samarinda to create a scientific paper that is following the rules. Based on the implementation of the training, it can be concluded that it is run well and received support from the school. All participants follow this activity until the end with an attendance rate of $100 \%$. They are enthusiastic to ask, explore, and express their ideas and opinions. Then, in the future, it is expected that there will be further activities involving the teachers to optimization the role of assistants to create their student's scientific papers.
\end{abstract}

Keywords: scientific paper,scientific rules, students. 


\section{PENDAHULUAN}

Perkembangan dan kemajuan ilmu sains dan teknologi yang cepat mempengaruhi kemajuan sebuah bangsa yang dapat diukur dari pembangunan manusia di dalamnya. Keberhasilan pembangunan kualitas hidup manusia dapat dilihat dari tinggi rendahnya nilai indeks yang lebih dikenal dengan istilah Indeks Pembangunan Manusia (IPM) (Azahari, 2000). Tiga dimensi dasar dalam penyusunan IPM, yaitu dimensi umur panjang dan hidup sehat, dimensi standar hidup layak, dan dimensi ilmu pengetahuan (BPS, 2016; UNDP, 2017). Masing-masing dimensi dasar merefleksikan ukuran yang berbeda-beda. Indikator dalam dimensi pengetahuan saat ini menjadi prioritas utama dalam pembangunan yang bertujuan untuk meningkatkan kualitas sumber daya manusia demi kemajuan, kemandirian dan mampu berdaya saing dalam era globalisasi.

Dimensi ilmu pengetahuan diukur menggunakan gabungan dari indikator angka harapan lama sekolah dan angka rata-rata lama sekolah. Kedua indikator ini menjadi ukuran tingkat keberhasilan dibidang pendidikan di suatu daerah (Riani, 2006). Semakin tinggi angka rata-rata harapan lama sekolah dan angka rata-rata lama sekolah, menunjukkan semakin tinggi pula tingkat pendidikan yang mampu dicapai oleh penduduk usia 15 tahun ke atas dalam menjalani pendidikan formal. Tingginya angka rata-rata harapan lama sekolah maupun angka rata-rata lama sekolah tidak serta merta menjadi ukuran mutlak dari keberhasilanpendidikan. Keberhasilan pendidikan dapat dipengaruhi oleh beberapa faktor yang menjadi bagian dalam sebuah sistim pedidikan.

Sistim pendidikan terbentuk dari beberapa unsur didalamnya yang memiliki perannya masing-masing. Siswa merupakan bagian penting dalam sebuah sistim pendidikan (Saat, 2015). Siswa sebagai penggerak masa depan bangsa sudah selayaknya memiliki pemikiran yang inovatif dan mampu memberikan solusi sederhana bagi persoalan di sekitar. Siswa yang unggul dan mampu bersaing di era globalisasi menjadi tumpuan untuk terwujudnya kemajuan pendidikan sebagai faktor keberhasilan suatu bangsa (Munirah, 2015).

Keunggulan siswa tidak hanya dapat dinilai dari sisi akademik, namun juga dari sisi non akademik. Penilaian keunggulan dari sisi akademik dapat dilakukan secara serentak dan lebih mudah, berbeda halnya dengan penilaian non-akademik. Penilaian non akademik dapat dinilai dari prestasi-prestasi yang mampu diraih oleh siswa dalam kegiatan diluar akademik, seperti kegiatan ekstrakulikuler bidang olahraga, seni, maupun karya tulis ilmiah.

Sekolah Menengah Atas Negeri (SMAN) 5 Samarinda, merupakan salah satu sekolah tingkat menengah atasdikotaSamarindayangmempunyai segudang prestasi baik bidang akademik maupun non akademik. Namun, prestasi non akademik khususnya pada bidang Karya tulis ilmiah (KTI) dinilai masih kurang. Hal ini dapat diketahui berdasarkan 
jajaran piagam penghargaan prestasi yang lebih didominasi dibidang olahraga maupun seni. Kemampuan siswa untuk menghasilkan ide kreatif dan inovatif sudah cukup baik, namun masih kurangnya keberanian dalam mengemukakan ide tersebut untuk menjadi sebuah karya tulis. Selain itu, pemahaman terkait konsep dasar dan aturan penulisan karya tulis ilmiah masih menjadi sebuah masalah bagi beberapa siswa.

KTI adalah karya ilmiah yang ditulis atau dikerjakan dengan mengikuti kaidah-kaidah ilmiah (Alie, 2015; Dwijayanti,dkk., 2017; Kasiyan,dkk., 2019; LIPI, 2012). Kaidah ilmiah sebagai syarat utama dalam penulisan sebuah karya ilmiah agar karya yang dihasilkan dapat dipertanggungjawabkan secara ilmiah. Oleh karena itu dalam menyusun KTI perlu membekali diri dengan dasar-dasar ilmu pengetahuan sesuai dengan bidang garapan KTI yang akan dikerjakan agar syarat kesesuaian dengan kaidah ilmiah dapat terpenuhi. Berdasarkan hal inilah, diadakannya pelatihan terkait penulisan karya tulis ilmiah dengan maksud untuk menumbuhkan minat, semangat, serta ide-ide kreatif dan inovatif dari siswasiswi SMAN 5 Samarinda untuk menghasilkan sebuah karya ilmiah yang tentunya sesuai dengan kaidah penulisan.

\section{METODE PENELITIAN}

Kegiatan ini dilakukan pada bulan September 2019, bertempat di SMAN 5 Samarinda, dengan peserta siswa-siswi kelas $\mathrm{X}$ dan XI. Tujuan utama dalam kegiatan ini yaitu menumbuhkan dan meningkatkan minat siswa-siswi untuk menulis sebuah karya ilmiah.

Materi yang disampaikan dalam pelatihan ini, yaitu bagaimana memunculkan ide-ide kreatif dan inovatif yang seringkali muncul dari permasalahan-permasalahan yang ada disekitar kita, serta bagaimana cara menulis sebuah karya tulis ilmiah yang sesuai dengan kaidah penulisan. Metode dalam penyampaian materi dilakukan dengan cara presentasi dari narasumber, dan dilanjutkan dengan diskusi serta praktik dalam memunculkan ide-ide kreatif.

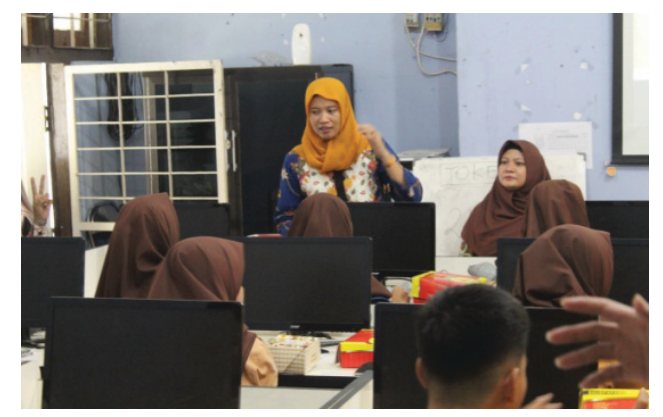

Gambar 1. Pemateri menjelaskan teknik penulisan karya tulis ilmiah.

\section{HASIL DAN PEMBAHASAN}

Pelatihan penulisan KTI bagi siswa-siswi SMAN 5 Samarinda mendapatkan respon yang sangat baik dari peserta pelatihan. Hal ini terlihat dari antusiasme peserta dalambertanya kepada pemateri. Dalam sesi diskusi, peserta kegiatan aktif bertanya dan mengemukakan pendapat serta ide sederhana yang mereka dapatkan.

Pada sesi praktik, peserta pelatihan dilatih untuk menuangkan ide yang mereka miliki, dengan menyebutkan variabel-variabel penelitian, analisis masalah, tujuan, 
serta pemilihan metode penelitian sederhana yang sesuai dengan gagasan yang diangkat. Dari hasil praktik, 90\% peserta mampu menggali gagasan sederhana untuk dituangkan dalam sebuah karya tulis. Diantaranya, satu peserta memaparkan gagasannya terkait bagaiman cara mendeteksi peralatan sekolah miliknya yang sering hilang. Maksud dari gagasan yang disampaikan yaitu ingin diciptakannya sebuah inovasi terbaru sebuah aplikasi yang dilengkapi sensor yang dapat digunakan melacak peralatan sekolah yang hilang.

Selain itu, ada juga peserta mengemukakan idenya terkait bagaimana metode pembelajaran yang efektif bagi siswa-siswi yang melaksanakan full day school agar tidak bosan dan penat. Seperti yang diketahui bahwa, dibeberapa kota di Indonesia, sudah banyak sekolahsekolah dari berbagai jenjang pendidikan yang menerapkan sistim full day school. Sistim full day school memiliki sisi positif maupun negatif. Peserta pelatihan yang notabene merupakan siswa sekolah full day school mengemukakan apa yang dirasakannya sebagai subjek dari sistim tersebut. Peserta pelatihan menyatakan bahwa, sistim full day school sebenarnya bagus, namun, saat jam siang kebanyakan muridmurid sudah mulai merasakan bosan dan penat dalam menghadapi mata pelajaran yang disampaikan. Peserta menyatakan, kurangnya waktu istirahat bagi murid full day school ternyata memberikan dampak yang kurang baik bagi siswa terutama saat mata pelajaran berlangsung di siang hari. Oleh karena itu, peserta pelatihan memiliki ide bagaimana metode pembelajaran yang efektif agar siswa full day school tidak bosan dan penat saat jam siang hari. Peserta mengemukakan bahwa dengan penambahan waktu istirahat dapat membuat pikiran mereka segar kembali. Selain itu diharapkannya adanya perubahan metode pengajaran dari guru-guru mata pelajaran, yakni berubah dari metode ceramah menjadi metode diskusi aktif. Peserta menceritakan bahwa, metode diskusi aktif, dapat membangun kedekatan antar guru dan siswa, siswa lebih aktif dan berani dalam untuk mengemukakan pendapat.

Peserta pelatihan lainnya, memaparkan ide kreatif terkait maraknya Body Shaming untuk diangkat menjadi satu topik yang menarik. Adapun latar belakang yang mendasari permasalahan yang diangkat yaitu maraknya kasus bullying dikalangan remaja yang berawal dari candaan terkait fisik mereka. Berdasarkan hal inilah, peserta pelatihan ingin mengangkat topik untuk mengetahui dampak dari perlakuan body shaming di sekitar sekolah mereka.

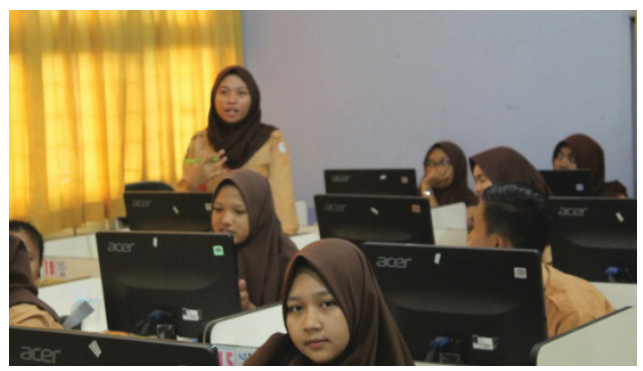

Gambar 2. Peserta pelatihan aktif bertanya terkait pemaparan teknik penulisan karya tulis ilmiah. 


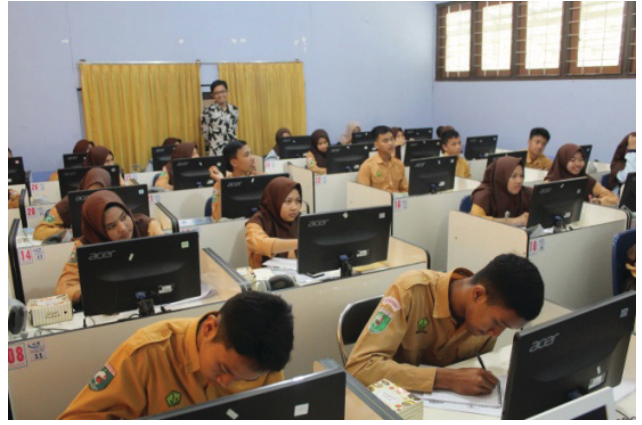

Gambar 3. Peserta pelatihan melakukan eksplorasi ide dan gagasan.

\section{SIMPULAN}

Berdasarkan kegiatan yang telah dilakukan di SMAN 5 Samarinda, maka dapat disimpulkan bahwa peserta pelatihan mampu untuk memunculkan ide kreatif dan inovatif terkait penanganan masalah disekitar mereka. Namun, kurangnya informasi terkait cara penulisan yang sesuai dengan kaidah ilmiah membuat peserta enggan untuk menulis. Oleh karena itu, kedepannya diharapkan adanya pelatihan lanjutan dengan target sasaran guru agar nantinya mampu membimbing dan membina siswa-siwinya secara optimal dalam menghasilkan sebuah karya tulis ilmiah.

\section{DAFTAR PUSTAKA}

Alie, M. 2015. Motivasi Widyaiswara

Dalam Penulisan Karya Tulis Ilmiah (Studi Kasus Pada Peserta Diklat Karya Tulis Ilmiah Di Lan 8 s.d. 12 Juni 2015). IRFANI $\therefore$ Journal of Islamic Education. Vol 11, No 1, 96-107.

Azahari, A. 2000. Pembangunan Sumberdaya Manusia Dan Indeks Pembangunan Manusia Sektor Pertanian 14. Jurnal
Ekonomi dan Bisnis Indonesia. Vol 15,No 1, 56-69.

BPS, 2016. Indeks Pembangunan Manusia 2015. BPS, Jakarta.

Dwijayanti, R., Marlena, N., Patrikha, F.D. 2017. Pelatihan Penulisan Karya Tulis (KTI) Bagi GuruGuru Smk Di Kabupaten Jombang. Jurnal Pemberdayaan Masyarakat Madani(JPMM). Vol 1, No 2, 249-266.

LIPI. 2012. Pedoman Karya Tulis Ilmiah. LIPI. Jakarta.

Munirah, M., 2015. Sistem Pendidikan

Di Indonesia: Antara Keinginan

Dan Realita. Auladuna: Jurnal

Pendidikan Dasar Islam. Vol 2

, No 2, 233-245.

Riani, W., 2006. Pembangunan Pendidikan Sebagai Motor Penggerak Ipm Jawa Barat 14. Mimbar Jurnal Sosial dan Pembangunan. Vol 22, No 3, 278-291.

Saat, S., 2015. Faktor-Faktor Determinan Dalam Pendidikan. Jurnal Al-Ta'dib. Vol 8, No 2, $1-17$.

UNDP, 2017. Human Development Report 2016: Human Development For Everyone.

Kasiyan., Zuhdi, B.M., Hendri, Z., Handoko, A., Sitompul, M. Pelatihan Penulisan Karya Ilmiah Untuk Peningkatan Profesionalisme Guru. Jurnal Pengabdian dan Pemberdayaan Masyarakat. Vol 3, No 1, 4753. 